\title{
ROLE OF HEPATIC STELLATE CELLS (HSCS) IN THE DEVELOPMENT OF HEPATIC FIBROSIS IN CATS WITH POLYCYSTIC KIDNEY DISEASE (PKD)
}

ALEKSIĆ-KOVAČEVIĆ SANJA*, KUKOLJ V*, KURELJUŠIĆ B B**, MARINKOVIĆ $D^{*}$, KNEŽEVIĆ Đ***, IGNJATOVIĆ $I^{* * *}$, JOVANOVIĆ $\mathrm{M}^{*}$, KNEŽEVIĆ MILIJANA* and GLEDIĆ $\mathrm{D}^{*}$

*University of Belgrade, Faculty of Veterinary Medicine, Serbia

$\star \star$ Institute of Veterinary Medicine of Belgrade, Serbia

*** Institute of Digestive Diseases, Clinical Center of Serbia, Belgrade

(Received 19th December 2009)

Hepatic stellate cells (HSCs) play a significant role in hepatic fibrogenesis. In the following study we described the distribution of cells that express alpha-smooth muscle actin ( $\alpha-S M A)$ and desmin in the cat liver with various degrees of fibrosis, as well as the significance of hepatic stellate cells and portal myofibroblasts in the genesis of fibrosis in cats with polycistic kidney disease.

Liver samples from 15 necropsied Persian cats were examined microscopically, using $H \& E$ and Masson-trichrom methods and immunohistology for $\alpha-S M A$ and desmin. Liver fibrosis was confirmed in cats with terminal stage of chronic cholangiohepatitis and it was characterized by connective tissue septa which divide the liver parenchyma into irregular lobuli.

Inflammation in the cat liver is connected with the activation of periductal myofibroblasts. The intensity of immunopositivity of perisinusoidal HSCs to $\alpha-S M A$ and desmin varied depending on the degree of fibrosis and was the strongest in livers of cats with cirrhosis.

Key words: cat, liver, fibrosis, HSCs, histopathology, immunohistochemistry

\section{INTRODUCTION}

The etiopathogenesis of chronic liver diseases in cats and dogs, including fibrosis and cirrhosis, has not been sufficiently clarified. Feline liver fibrosis is caused by many chronic diseases (Knežević et al., 2009; Kureljušić et al., 2009; Bataller and Brenner, 2005; Watson, 2004; Center, 1999; Adamus et al., 1997). In Persian and Persian-cross cats chronic liver disease develops in animals with polycystic kidney disease (PKD). Lymphocytic pericholangitis is often associated with this disease, and occasionally it ends up in hepatic fibrosis (Jovanović et al., 2004).

Liver fibrosis is defined as a detectable deposit of extracellular matrix and it can develop into cirrhosis, characterized by disruption of normal hepatic 
architecture (Bataller and Brenner, 2005). Hepatocytes apoptosis and inflammatory cells trigger the secretion of profibrogenic and proinflammatory cytokines (TGF- $\beta 1$, angiotensin II, leptin), which in turn activate hepatic stellate cells (HSCs), the major source of collagen type I (Eng and Friedman, 2000). Activated fibroblasts, which develop myofibroblastic characteristics, play an essential role in hepatic fibrogenesis. They comprise 3 subpopulations: 1) portal or septal myofibroblasts, 2) interface myofibroblasts and 3) perisinusoidally located HCSs (Knežević et al. , 2009; Kukolj et al., 2009; Moreira, 2007; Friedman, 2000).

HSCs represent a highly versatile cytotype that play a significant role in liver development and differentiation, regeneration, immunoregulation, control of hepatic blood flow and inflammatory reactions (Zhao and Burt, 2007; Safadi and Friedman, 2000). Concerning their role in fibrosis and extracellular matrix (ECM) remodelling and that they may produce and secrete a wide panel of molecular intermediates, HSCs are definitely involved in the pathogenesis of various liver diseases. In particular, they can actively contribute to the progression of hepatitis and steatohepatitis of different aetiology, as well as liver carcinogenesis (Moreira, 2007; Friedman, 2000).

We described the distribution and localization of cells that express alphasmooth muscle actin ( $\alpha$-SMA) and desmin in the liver of cats with various degrees of fibrosis, as well as the significance of HSCs and portal myofibroblasts in the genesis of fibrosis in cats with PKD.

\section{MATERIAL AND METHODS}

Liver samples of 15 Persian cats, of different gender, on which autopsies were performed at the Department of Pathology of the Faculty of Veterinary Medicine of the University of Belgrade were examined. The cats were 7-36 months old. The histological criteria for the selection of the examined samples were defined on the basis of criteria reported by Boisclair et al. (2001). Based on the degree of fibrosis, livers were classified into three groups: 1- mild portal fibrosis; 2 - moderate portal fibrosis with mild periportal and septal fibrosis; 3 - severe portal fibrosis with marked periportal and septal fibrosis or cirrhosis. Normal liver sections obtained from five cats without evidence of infectious, neoplastic, or cardiac disease were used as controls.

Liver samples were fixed in $10 \%$ buffered formalin, and, after standard processing in an automated tissue processor, cast in paraffin blocks. Paraffin sections 3-5 $\mu \mathrm{m}$ thick were stained with hematoxylin and eosin and with Masson's trichrome for light microscopic examination.

Three-step indirect immunohistochemical technique was performed. After antigen retrieval and inactivation of endogenous peroxidase, the sections were incubated with appropriate primary antibodies diluted in PBS (Table 1). All rinsing procedures and serum dilutions were done in PBS (pH 7.2). The detection kit was LSAB2 System-HRP, Rabbit/mouse (DAKO, K0675). Reactions were visualized by using $\mathrm{DAB}+(\mathrm{DAKO}, \mathrm{K} 3468)$ and counterstaining with hematoxylin. Smooth 
muscle cells within the blood vessel wall were used as internal positive controls for $\alpha$-SMA and desmin. controls.

Liver sections not treated with the primary antibody were used as negative

Table 1. Primary antibodies used for immunohistochemistry

\begin{tabular}{|c|c|c|}
\hline Antibodies & Source & Dilution \\
\hline \hline Desmin D33 & DAKO M0760 & $1 / 100$ \\
\hline$\alpha$-SMA 1A4 & DAKO M0851 & $1 / 50$ \\
\hline
\end{tabular}

Semiquantitive analysis

Semiquantitative scoring for each parameter was performed independently by 2 of the authors. The scoring method applied was based on the system used by Mekonnen et al., 2007 with the modification as described in Table 2.

Table 2. Criteria used in semiquantitative scoring of feline fibrotic livers

\begin{tabular}{|c|c|c|c|c|}
\hline \multirow{2}{*}{ Parameters } & \multicolumn{4}{|c|}{ Criteria Employed for Scoring } \\
\hline & Absent $(0)$ & Mild (1) & Moderate (2) & Severe (3) \\
\hline $\begin{array}{l}\text { Degenerative/ } \\
\text { Necrotic } \\
\text { Hepatocytes }\end{array}$ & $\begin{array}{l}\text { No apoptosis/ } \\
\text { degeneration }\end{array}$ & $\begin{array}{l}\text { Few focal/ } \\
\text { diffuse } \\
\text { degeneration/ } \\
\text { necrotic } \\
\text { hepatocytes }\end{array}$ & $\begin{array}{l}\text { Moderate } \\
\text { multifocal or } \\
\text { semizonal/ diffuse } \\
\text { degeneration/ } \\
\text { necrosis }\end{array}$ & $\begin{array}{l}\text { Confluent and } \\
\text { bridging necrosis } \\
\text { containing larger } \\
\text { areas in random or } \\
\text { zonal pattern of } \\
\text { distribution }\end{array}$ \\
\hline $\begin{array}{l}\text { Inflammatory } \\
\text { cells }\end{array}$ & $\begin{array}{l}\text { No } \\
\text { inflammatory } \\
\text { cells }\end{array}$ & $\begin{array}{l}\text { Small numbers } \\
\text { of inflammatory } \\
\text { cells restricted } \\
\text { to portal/septal } \\
\text { and/or central } \\
\text { areas }\end{array}$ & $\begin{array}{l}\text { Moderate number } \\
\text { of inflammatory } \\
\text { cells in } \\
\text { parenchyma; } \\
\text { central, septal/ } \\
\text { portal, or } \\
\text { regenerative areas }\end{array}$ & $\begin{array}{l}\text { Diffuse or multifocally } \\
\text { distributed } \\
\text { inflammatory cells in } \\
\text { parenchyma; } \\
\text { perivascular, } \\
\text { septal/portal, nodular } \\
\text { regeneration }\end{array}$ \\
\hline $\begin{array}{l}\text { Stage of } \\
\text { Fibrosis } \\
\text { (based on } \\
\text { Masson } \\
\text { trichrome and } \\
\text { H\&E staining) }\end{array}$ & No fibrosis & $\begin{array}{l}\text { Mild portal/ } \\
\text { centrilobular } \\
\text { fibrosis }\end{array}$ & $\begin{array}{l}\text { Moderate } \\
\text { portal/centrilobular } \\
\text { fibrosis with mild } \\
\text { periportal, septal } \\
\text { and parenchymal } \\
\text { fibrosis; spurus } \\
\text { radiating into } \\
\text { parenchyma with } \\
\text { normal lobular } \\
\text { architecture }\end{array}$ & $\begin{array}{l}\text { Severe fibrosis with } \\
\text { marked periportal/ } \\
\text { centrilobular and } \\
\text { septal fibrosis; } \\
\text { bridging fibrosis with } \\
\text { loss of lobular } \\
\text { architecture with } \\
\text { nodular regeneration/ } \\
\text { cirrhosis }\end{array}$ \\
\hline
\end{tabular}


cont. Table 2.

\begin{tabular}{|c|c|c|c|c|}
\hline \multirow{2}{*}{ Parameters } & \multicolumn{4}{|c|}{ Criteria Employed for Scoring } \\
\hline & Absent (0) & Mild (1) & Moderate (2) & Severe (3) \\
\hline $\begin{array}{l}\text { Bile Duct } \\
\text { Proliferation } \\
\text { (based on } \\
\text { H\&E staining) }\end{array}$ & $\begin{array}{l}<3 \text { Bile ducts } \\
\text { per portal } \\
\text { triads }\end{array}$ & $\begin{array}{l}\text { 3-5 Bile ducts } \\
\text { per portal } \\
\text { triads/septa }\end{array}$ & $\begin{array}{l}\text { 5-7 Bile ducts per } \\
\text { portal triads/septa } \\
\text { plus a few bile } \\
\text { ducts in } \\
\text { parenchymal and } \\
\text { around } \\
\text { regenerative } \\
\text { nodules }\end{array}$ & $\begin{array}{l}>7 \text { Bile ducts per } \\
\text { portal triads/septa } \\
\text { and many bile ducts } \\
\text { in parenchyma and } \\
\text { around the } \\
\text { regenerative nodules }\end{array}$ \\
\hline $\begin{array}{l}\alpha \text {-SMA } \\
\text { expression }\end{array}$ & \multicolumn{4}{|c|}{$\begin{array}{l}\text { Perisinusoidal lininig: absent to strong for each location }=0-3 \\
\text { Necrotic areas of lobule } \\
\text { Regenerative nodules } \\
\text { Normal lobule } \\
\text { Septal/portal triads: absent to strong for each location = 0-3 } \\
\text { Bile ducts } \\
\text { Blood vessels } \\
\text { Stroma } \\
\text { Portal-parenchymal interface areas: absent to strong =0-3 } \\
\text { Around regenerative nodules: absent to strong }=0-3\end{array}$} \\
\hline $\begin{array}{l}\text { Desmin } \\
\text { expression }\end{array}$ & \multicolumn{4}{|c|}{$\begin{array}{l}\text { Perisinusoidal lininig: absent to strong for each location = 0-3 } \\
\text { Necrotic areas of lobule } \\
\text { Regenerative nodules } \\
\text { Normal lobule } \\
\text { Septal/portal triads: absent to strong for each location = 0-3 } \\
\text { Bile ducts } \\
\text { Blood vessels } \\
\text { Stroma } \\
\text { Portal-parenchymal interface areas: absent to strong =0-3 } \\
\text { Around regenerative nodules: absent to strong }=0-3\end{array}$} \\
\hline
\end{tabular}

\section{RESULTS}

\section{Histopathology}

Different hepatic lesions (hepatocellular degeneration, necrosis and inflammation) were observed in all affected cats. Liver cysts were present in 2 of 15 affected cats (13.3\%), but in none of the controls. The most common lesion was mild to severe biliary fibrosis and hyperplasia. Liver fibrosis of different degree was present in 14 of 15 affected cats (93.3\% - Table 3$)$.

Liver sections with mild portal fibrosis (33.3\%) showed an increased amount of edematous connective tissue with a small number of mononuclear cells in the portal area (Figure 1).

Sections with second degree fibrosis $(40.0 \%)$ were characterized with the presence of connective tissue in the portal area which spreads between hepatocytes of neighboring lobuli (Figure 2). 
Table 3. Mean scores of evaluated criteria at different stage of hepatic lesion in PKD affected cats

\begin{tabular}{|l|c|c|c|c|}
\hline \multirow{2}{*}{ Variables } & \multicolumn{4}{c|}{ Score per stage of fibrosis } \\
\cline { 2 - 5 } & 0 & 1 & 2 & 3 \\
\hline \hline $\begin{array}{l}\text { Hepatocellular degeneration } \\
\text { and necrosis }\end{array}$ & 3.0 & 2.7 & 2.5 & 3.0 \\
\hline Inflammatory cells & 1.0 & 1.5 & 1.2 & 2.0 \\
\hline Bile duct proliferations & 0.0 & 2.3 & 3.0 & 3.0 \\
\hline$\alpha$-SMA & 1.4 & 2.2 & 2.4 & 2.8 \\
\hline Desmin & 1.1 & 1.8 & 2.1 & 2.4 \\
\hline
\end{tabular}

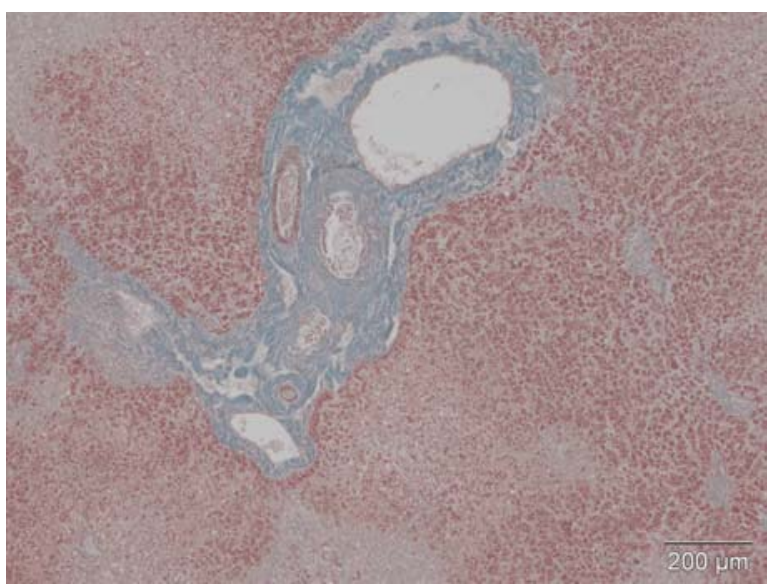

Figure 1. Cat liver portal fibrosis, Masson's trichrome, 100x

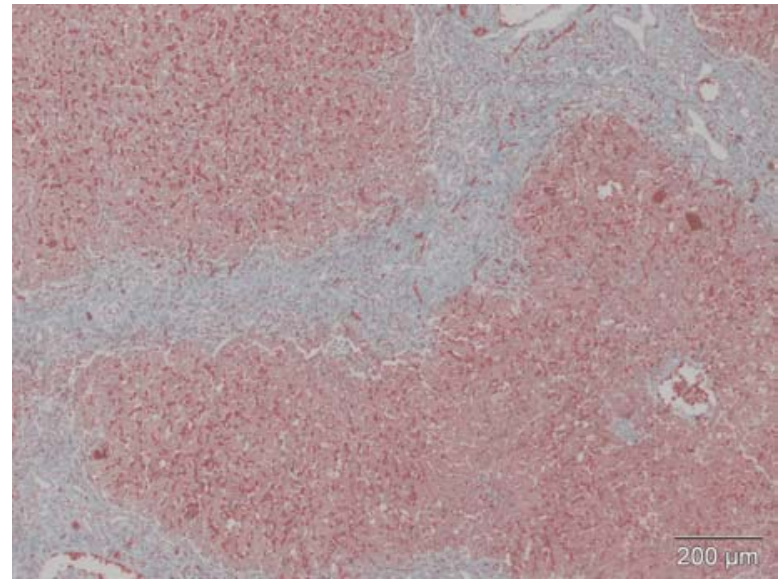

Figure 2. Cat liver bridging fibrosis, Masson's trichrome, 100x 
Feline livers with third degree fibrosis (20.0\%) showed a significantly greater amount of connective tissue compared to the previous group (Figure 3). Connective tissue septa divide liver parenchyma into lobuli of irregular shape and varying sizes (Figure 4). Chronic mononuclear cellular infiltrate, blood vessels with hyalinized wall and a narrowed lumen, a large number of bile ducts and cholestasis were also frequently noticed in abundant connective tissue.

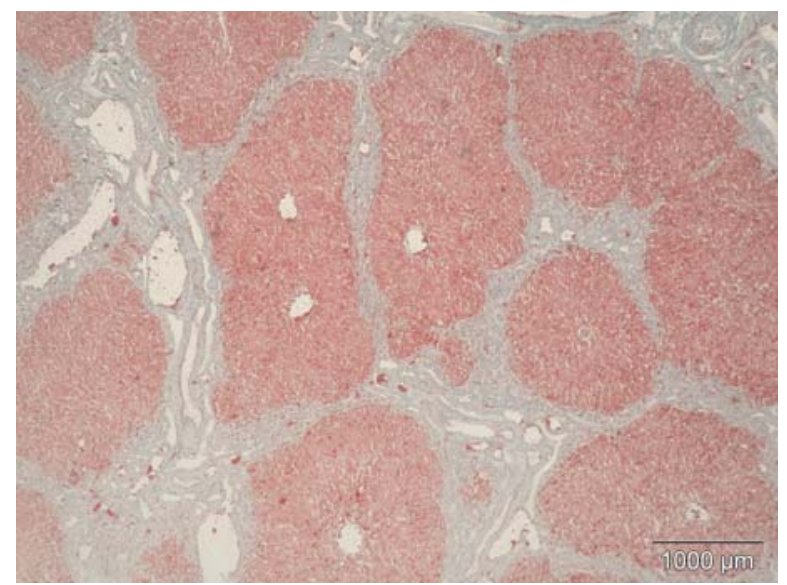

Figure 3. Cat liver cirrhosis with pseudo-lobules, Masson's trichrome, 40x

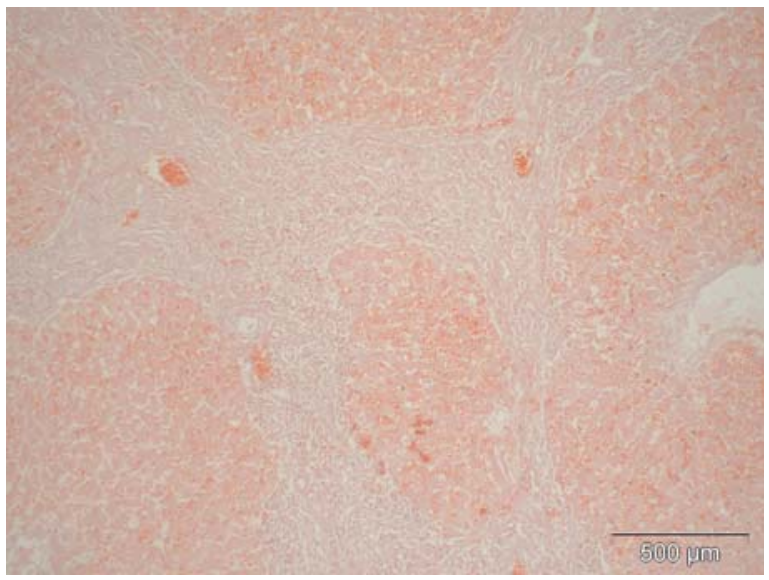

Figure 4. Cat liver bridging fibrosis with marked fibrous septa, HE, 100x

Immunohistochemistry

In all control liver samples, moderately discontinuous reactivity to $\alpha$-SMA was observed in the spaces of Disse, randomly distributed around the bile ducts and blood vessels and under the Glisson's capsule. Mild positive reaction to desmin was observed in portal blood vessels and some perisinusoidal cells. 
In the mildest forms of fibrosis $\alpha$-SMA was expressed in some perisinusoidal cells and cells in connective tissue of portal areas and fibrous septa. In the livers with moderate to severe fibrosis numerous $\alpha$-SMA positive cells, presumable myofibroblasts, were present in the fibrous septa, and stroma surrounnding regenerative nodules. Mild positive reaction to desmin was restricted to the wall of blood vessels of portal triads and to perisinusoidal cells.

In livers with periportal and septal fibrosis $\alpha$-SMA was detected in round and spindle-shaped cells around bile ducts and blood vessel walls. Scarce interface stellate cells and perisinusoidal cells with processes showed an intensive positive reaction to $\alpha$-SMA. Lipid vacuoles were visible in some cells in perisinusoidal position. In fibrous septa a positive reaction to desmin was detected in myofibroblasts and blood vessels, as well as in some perisinusoidal cells at the periphery of lobuli.

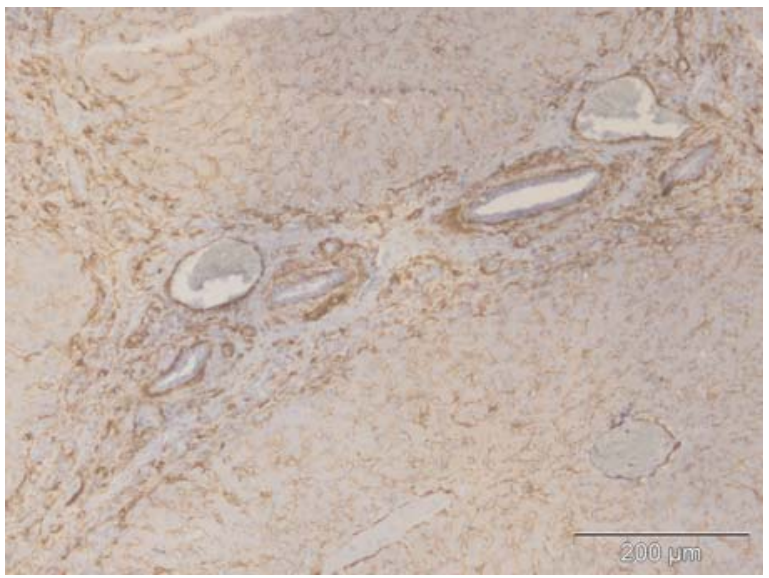

Figure 5. Cat liver cirrhosis, $\alpha$-SMA positive cells, LSAB2, 200x

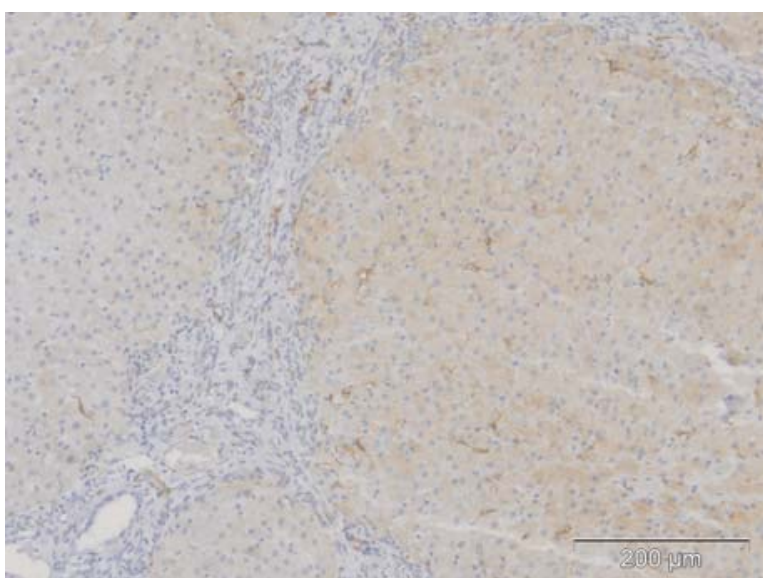

Figure 6. Cat liver cirrhosis, desmin positive cells, LSAB2, 200x 
Acta Veterinaria (Beograd), Vol. 60, No. 2-3, 391-400, 2010.

Aleksić-Kovačević Sanja et al.: Role of hepatic stellate cells (HSCs) in the development of hepatic fibrosis in cats with polycystic kidney disease (PKD)

In livers with severe fibrosis and cirrhosis $\alpha$-SMA was observed in fibrotic stroma surrounding negatively "stained" regenerative lobuli, as well as in normal lobuli in perisinusoidal cells (Figure 5). Besides the wall of blood vessels of portal triads and myofibroblasts in fibrous septa intensive positive reaction to desmin was observed in oval to spindle-shaped cells in perisinusoidal spaces of normal lobuli (Figure 6).

The intensity of reaction to $\alpha-S M A$ and desmin was in positive correlation with the degree of fibrosis (Table 3 ).

\section{DISCUSSION}

Hepatic lesions are concomitant with renal lesions in cats with ADPKD (Stebbins, 1989; Eaton et al., 1997). In humans, the occurrence of hepatic cysts increases with age and severity of disease, as it also appears to do in Persian cats with naturally occurring PKD. An interesting observation reported in this study was the high frequency of hepatobiliary hyperplasia, similar to congenital hepatic fibrosis, in affected cats. In human patients, congenital hepatic fibrosis is most commonly associated with ARPKD, but is also associated with ADPKD, particularly in some families.

The explanation for the differences in hepatic lesions in families is not known, but genetic differences among families may be involved. ADPKD in human beings has been associated with as many as three different chromosomal loci. The gene or genes for ADPKD in cats and their relationship to human genes have not been identified yet (Young et al., 2005).

Compared to other animal models, the mechanism of development of liver fibrosis is very similar in cats and dogs. The only difference between the two species is the intensity of expression of $\alpha$-SMA and desmin in particular stages of fibrosis, which is the result of increased activity of myofibroblasts i.e. increased ECM production.

Liver injury results in activation of collagen-producing cells and excessive deposition of ECM proteins. This process is orchestrated by many cell types. Hepatocytes apoptosis and inflammatory cells trigger the secretion of cytokines, such as TGF- $\beta 1$, angiotensin II, leptin, which in turn activate HSCs, the major source of collagen type I (Eng and Friedman, 2000; Safadi and Friedman, 2002). Myofibroblasts also play an essential role in hepatic fibrogenesis (Friedman, 2000; Moreira, 2007; Zhao and Burt, 2007).

During hepatic fibrogenesis in man and rat HSCs increase in number and differentiate into myofibroblast-like cells with a marked expression of $\alpha$-SMA (Cassiman et al. , 2002). The relatively recent recognition of HSCs as key elements in the development of liver fibrosis led to an unprecedented interest in this cell type (and its activated form) as a prognostic indicator of progression of liver fibrosis, as well as a potential target for therapeutic intervention to prevent the development of cirrhosis (Moreira, 2007; Mekonnen et al., 2007).

Antibodies to $\alpha$-SMA and to a lesser extent desmin were proved to be useful markers for myofibroblasts in feline liver fibrosis. In our study inflammatory activity 
showed a close relation to feline fibrosis. In the normal cat liver $\alpha$-SMA reactivity was observed in perisinusoidal cells and cells randomly distributed around a few bile ducts and blood vessels and under the Glisson's capsule. Mild positive reaction to desmin was observed in blood vessels of portal areas and some perisinusoidal cells.

Both $\alpha$-SMA and desmin expression increased as the degree of fibrosis increased. This may be the result of continuous activation of HSCs and myofibroblasts during hepatitis and synthesis of large amounts of ECM proteins. In chronic hepatitis, fibrotic extensions begin at the branching point of the preterminal portal tract bridging the neighboring portal area. They are the consequence of ECM deposition by $\alpha$-SMA positive myofibroblasts and by the other cells located at the interface between the portal area and the parenchyma. In the mildest form of fibrosis a positive reaction to $\alpha$-SMA was revealed in the connective tissue of portal triads and perisinusoidal cells. Livers with moderate to severe fibrosis showed numerous $\alpha$-SMA positive cells in the portal triads, fibrotic septa, and stroma surrounding regenerative nodules, interpreted as activated myofibroblasts.

The presented results support an essential role of HSCs and myofibroblasts in the development of hepatic fibrosis in cats with terminal stage of pericholangitis.

\title{
ACKNOWLEDGEMENTS:
}

This work was supported by the Ministry of Science and Technological Development, Republic of Serbia, Project No 156010.

\author{
Address for correspondence: \\ Dr. Sanja Aleksić-Kovačević \\ Department of Pathology \\ Faculty of Veterinary Medicine \\ University of Belgrade \\ Bulevar oslobodjenja 18 \\ 11000 Belgrade, Serbia \\ E-mail: skovacevic@vet.bg.ac.rs
}

\section{REFERENCES}

1. Adamus C, Buggin-Daubie M, Izembart A et al., 1997, Chronic hepatitis associated with leptospiral infection in vaccinated beagles, J Comp Path, 117, 4, 311-28.

2. Bataller R, Brenner DA, 2005, Liver fibrosis, J Clin Invest, 115, 2, 209-18.

3. Boisclair J, Dore M, Beauchamp G, Chouinard L, Girard C, 2001 Characterization of the inflammatory infiltrate in canine chronic hepatitis, Vet Pathol, 38, 6, 628-35.

4. Cassiman D, Libbrecht L, Desmet V, Denef C, Roskams T, 2002, Hepatic stellate cell/myofibroblast subpopulations in fibrotic human and rat livers, $J$ Hepatol, 36, 2, 200-9.

5. Center SA, 1999, Chronic liver disease: current concepts of disease mechanisms, J Small Anim Pract, 40, 3, 106-14.

6. Eaton A, Biller DS, Dibartola SP, Radin MJ, Wellman ML, 1997, Autosomal dominant polycystic kidney disease in Persian and Persian-cross cats, Vet Path, 34, 2, 117-26.

7. Eng FJ, Friedman SL, 2000, Fibrogenesis I. New insights into hepatic stellate cell activation: the simple becomes complex, Am J Physiol Gastrointest Liver Physiol, 279, 1, G7-G11. 
8. Friedman S, 2000, Molecular regulation of hepatic fibrosis an integrated cellular response to tissue injury, J Biol Chem, 275, 4, 2247-50.

9. Jovanović $M$, Aleksić-Kovačević S, Marinković D, Jelesijević T, Knežević $M, 2004$, Is the feline cholangiohepatitis complex genetically related. Proceedings of $22^{\text {nd }}$ Meeting of the European Society of Veterinary Pathology, Olsztyn, Poland, 111.

10. Knežević $M$, Gledić $D$, Kukolj V, Knežević Dj, Jovanović $M$, Božić $T$ et al., 2009, Expression of $\alpha$ SMA, desmin and vimectin in canine liver with fibrosis, Acta Vet, 59, 4, 361-70.

11. Kukolj V, Aleksić-Kovačević S, Jovanović M, Gledić D, Knežević M, 2009, Uloga zvezdastih (stelata) ćelija u nastanku fibroze jetre kod pasa. XIII Kongres Udruženja patologa i citologa Srbije sa međunarodnim učešćem, Vršac, Materia Medica, 25, 2, 34.

12. Kureljušić B, Marinković D, Obadović J, Đorđević M, Kukolj V, 2009, Histopatološka procena najčešćih oboljenja jetre kod mačaka, Veterinarski glasnik, 63, 1-2, 103-12.

13. Mekonnen GA, ljzer J, Nederbragt $H$, 2007, Tenascin-C in chronic canine hepatitis: Immunohistochemical localization and correlation with necro-inflammatory activity, fibrotic stage, and expression of alpha-smooth muscle actin, cytokeratin 7, and CD3+ cells, Vet Pathol, 44, 6, 803-13.

14. Moreira RK, 2007, Hepatic stellate cells and liver fibrosis. Arch Pathol Lab Med, 131, 11, 1728-34.

15. Safadi R, Friedman SL, 2002, Hepatic fibrosis - role of hepatic stellate cell activation. Med Gen Med, 4, 3, 27.

16. Stebbins KE, 1989, Polycystic disease of the kidney and liver in an adult Persian cat. J Comp Pathol, 100, 3, 327-30.

17. Watson PJ, 2004, Chronic hepatitis in dogs: a review of current understanding of the aetiology, progression and treatment, Vet $J, 167,3,228-41$.

18. Young AE, Biller DS, Herrgesell EJ, Roberts $H R$, Lyons $L A, 2005$, Feline polycystic kidney disease is linked to the PKD1 region. Mamm Genome, 16, 1, 59-65.

19. Zhao L, Burt AD, 2007, The diffuse stellate cell system, J Mol Hist, 38, 1, 53-64.

\section{ULOGA HEPATIČNIH ZVEZDASTIH ĆELIJA (HSCs) U RAZVOJU FIBROZE JETRE MAČAKA SA POLICISTIČNIM BUBREZIMA (PKD)}

ALEKSIĆ-KOVAČEVIĆ SANJA, KUKOLJ V, KURELJUŠIĆ B, MARINKOVIĆ D, KNEŽEVIĆ Đ, IGNJATOVIĆ I, JOVANOVIĆ M, KNEŽEVIĆ MILIJANA i GLEDIĆ D

\section{SADRŽAJ}

U ovom radu je opisana distribucija ćelija koje eksprimiraju $\alpha$-glatkomišićni aktin ( $\alpha$-SMA) i dezmin u jetri mačaka sa različitim stadijumom fibroze, kao i značaj ovih ćelija u razvoju fibroze, kod mačaka sa policističnim bubrezima.

Mikroskopski su ispitani uzorci jetre od 15 obdukovanih persijskih mačaka, korišćenjem HE i Mason-trihromnog bojenja i imunohistohemijski na $\alpha$-SMA i dezmin. Fibroza jetre potvrđena je kod mačaka sa terminalnim stadijumom hroničnog holangiohepatitisa i odlikovala se prisustvom vezivno-tkivnih septi koje dele parenhim na nejednake lobuluse.

Inflamacija u jetri mačaka u vezi je sa aktivacijom periduktalnih miofibroblasta. Intenzitet imunohistohemijske reakcije perisinusoidnih HSCs na $\alpha$-SMA i dezmin razlikovala se od stepena fibroze i bio je najjači u jetri mačaka sa cirozom. 